\title{
斜面および土構造物の地震危険度の統計的解析
}

\section{STUDY ON SEISMIC RISK ANALYSIS OF SLOPES AND EARTH STRUCTURES}

\author{
松尾稔* ・板 橋一雄** \\ By Minoru MATSUO and Kazuo ITABASHI
}

\begin{abstract}
The purpose of the present paper is to propose a methodology of the seismic risk analysis of slopes and earth structures based on the seismic coefficient. First, attenuation study of peak acceleration for various earthquakes in Japan is made and this shows noticeable scatterness depending upon the region of the earthquake. Second, the records of about twenty thousands earthquakes which occured in Japan are investigated to determine the area of "earthquake nest" and Gutenberg-Richter's equation is given for each "earthquake nest." These results are incorporated with the seismic risk analysis assuming the circular seismic source and poisson process as a seismic source model. The actual cases are analysed/by the proposed method and they show the validity of the method to distinguish the failure case and non-failure case.
\end{abstract}

\section{1. まえがき}

著者らは斜面や土構造物に関する実用性のある耐震設 計法や耐震診断法の開発を最終目標として研究を進めて いる.そのためには, (1)耐震計算法, (2)地震時の土の挙動, (3)地震外力の評価法, (4)耐震設計・診断規準の設定法が 必要となる．特に，地震外力の評価には，ビれくらいの 頻度でどの程度のマグニチュードの地震が発生するかと いう地震活動度，および建設地点にどれくらいの頻度で どの程度の地震動が到来するかという地震危険度の両問 題の解決が必要である11. 上記の目標を達成するために, 著者らは斜面や土構造物の地震被災事例の収集・整理, 震度法・円弧すべり面法による破壊事例・非破壊事例の 解析, 地震動記録の収集・解析を行ってきた ${ }^{2), 3)}$. その 結果，(1)被災形態がすべり破壊であると判断される事例 が全体の被災事例のうち $70 \%$ 程度あること,(2)震度法・ 円弧すべり面法により，地震時の斜面や土構造物の破 壊・非破壊の大略の判断が可能であること, (3)震度法の 基本的思想に従い, 加速度の代表値として最大加速度で

* 正会員 工博 名古屋大学教授 工学部地盤工学教室 ( 4464 名古屋市千種区不老町)

** 正会員 工修 名城大学助手 理工学部土木工学科 （テ468 名古屋市天白区塩釜口 1-501）
はなく, 破壊に寄与した平均的加速度を用いるべきだと の考えに立ち加速度時系列記録の移動平均を行った結 果, 最大加速度と移動平均加速度の最大値との間にはき わめて高い相関があり, 結果的に最大加速度を地震動の 1 つの代表値として利用してよいことを明らかにした. また, (4)震度法・円弧すべり面法により被災事例を逆解 析して求めた震度 (逆算震度) と各地震の距離娍衰式か ら推定される最大加速度との関係は，かなりのばらつき はあるものの, 平均的にみると直線関係にあることがわ かった。

本論文では上記結果を基礎において, 斜面や土構造物 の地震危険度解析について述べる. その基本的な方法論 はすでに Cornellit)が示したものであるが，これに日本 およびその周辺の地震発生状況, 最大加速度の距離減衰 式の地域性ならびに震度と最大加速度の関係を加味し て, わが国における斜面や土構造物の耐震設計・診断に 適用できるよう努めている. 必要上まず初めに, Cornell が示した方法論と新しく加味した点を略述して おきたい.

Cornell が示した地震危険度解析に必要な項目は, (1) 地震動パラメーター（最大加速度など）の距離減衰式, (2)地震源モデル, (3)地震源で生ずる地震マグニチュード, (4)地震の時間的発生過程, である. Cornell は地震動パ 
ラメーターとして, 修正メルカリ強度と最大地震動パラ メ一ター(最大加速度なぼ)の両者を考えている.そして, 後者については金井 ${ }^{5)}$ や Esteva and Rosenblueth ${ }^{6)}$ の提 案による周知の関係式を用いている. 最大加速度が地震 動の 1 つの代表值となり得ることを上に述べたが，著者 らは日本国内の最大加速度の実測值を用い, 距離減衰式 の重回帰分析を行った. その場合, 地壳構造の地域性を 考慮するために, 地震発生地点の地域別距離減衰式を提 案している. その詳細については2. で述べる. また最 大加速度と震度の関係も考慮し, 斜面や土構造物の地震 危険度を評価するパラメーターとして震度を用いること にした.

地震源モデルとして Cornell は, 距離に関する確率密 度関数が比較的簡単な形となるよう, 線震源と環状震源 （その一部を考えれば扇状震源）を考え, その地震源内 では一様に地震が発生すると仮定している. 地震源につ いては3. で詳述するが，日本の地震発生状況では線震 源や環状震源は考えにくい，そこで，本論文では円形震 央分布域（以下では簡便のためにこれを円形震源モデル と記す)を仮定して距離に関する確率密度関数を求めた. また, Cornell は地震源で生ずる地震マグニチュードに 関しては Gutenberg-Richter の関係, 地震発生過程に 関してはポアソン過程を仮定している．著者らも日本付 近の地震源で生ずる地震マグニチュードの整理を行い, Gutenberg-Richter の関係を求めるとともに, 地震マグ ニチュードの確率密度関数も求めた. 上述した点を考慮 し, 4. では斜面や土構造物の震度による地震危険度解 析の方法を簡単に示し, 同時に宮城県沖地震のときに破 壊した吉田川堤防の事例解析結果を示す.

\section{2. 最大加速度の距離減衰式}

建設予定地点で地震時の最大加速度を推定するために は，一般に距離と地震マグニチュードにより決まるとす る距離減衰式に頼らざるを得ない。ここでは従来の提案 式について簡単に触れ，その後に地域区分を考えた距離 減衰式を提示する.

\section{（1）従来の研究について}

河角 ${ }^{7)}$ は, 震度階, 地震マグニチュード, 震央距離 (あ るいは震源距離）間の関係を示し, 河角マップを作成し た. 岡本ら ${ }^{8)}$ は岩盤内の, また大崎ら ${ }^{9)}$ は硬質地盤上の 加速度記録を用いて, 距離減衰式を作成している. 勝又 ${ }^{10}$ は震央付近の上限最大加速度および震源域の端からの距 離を，また片山神は最大加速度の水平 2 成分を考慮して 式を提案している. 岩崎ら ${ }^{12)}$ は地盤種別を考慮し, さら に川島ら ${ }^{13)}$ は時刻歴を取り入れて重回帰分析を実施して いる. いずれも, 研究, 実用の両面において卓越した成 果であることはいうまでもないが，本論文では後述する

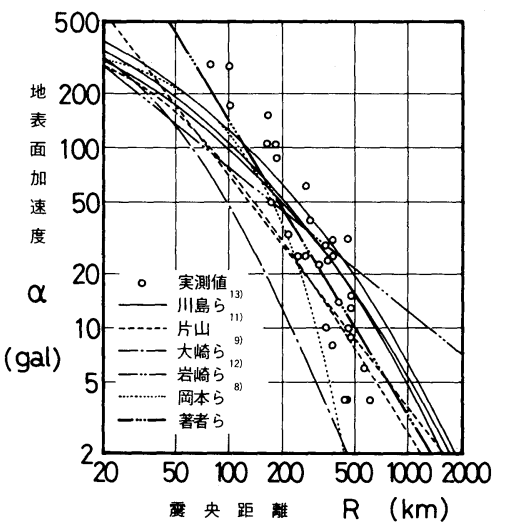

図一1 地表面加速度と距離減衰式 (宮城県沖地震の場合)

ように，斜面や土構造物の解析精度を少しでも上げるた め，地域別の距離減衰式を必要としたのである.

1978 年に 2 つ大きな地震が発生している．宮城県 沖地震 $(M=7.4)$ と伊豆大島近海地震 $(M=7.0)$ で ある.これらの地震時には多くの地点で地表面加速度が 测定されているので, 観測值をまず上述した距離減衰式 と比較してみた。図一1 は宮城県沖地震に関するもので ある. 図中の丸印は地表面で測定された最大加速度であ $り^{14), 15)}$ ，震央距離に対して図示してある．種々の線は前 述の各提案式に地震マグニチュード 7.4 を代入して得ら れた関係である.岡本らの関係は岩盤内の, また大崎ら の関係は硬質地盤上の記録に基づいた関係であるためと 思われるが, 測定值の方がかなり上側にある.また,片山， 岩崎ら, 川島らの関係と比較すると, 震央距離の短いと ころで大きな観測值が，震央距離の長いところで少し小 さめの観測值が得られている。しかし，これらの関係は 日本全体の加速度記録を説明するために作成されたもの であって，ローカルな影響をも精度高く説明しようと意 図されたものでないことを考えれば，この程度の外れは むしろ当然であり，批判するには当たらない.

図一2 は伊豆大島近海地震に関する同様の図である.

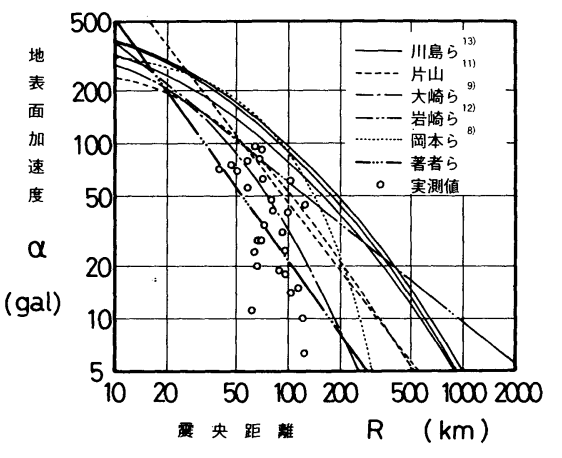

図一2 地表面加速度と距離減衰式（伊豆大島近海地震の場合） 
やはり丸印が地表面で測定された最大加速度であり ${ }^{16)}$, 震央距離に対して図示してある. また，各提案式に地震 マグニチュード 7.0 を代入した関係も示した。この図か ら観測された地表面加速度は各提案式よりもかなり小さ く地域性がより顕著に現われている．なお，両地震の実 測値を比較すると，図一2の伊豆大島近海地震の場合に は地震マグニチュードの割には小さな地表面加速度しか 測定されていないうえ，震央距離に対する減衰がかなり 大きく，両者の地震マグニチュードの相違以上に差があ るように思われる。

以上の結果からも, 最大加速度の距離減衰式を距離と 地震マグニチュードのみの関数とするには限界が感じら れる. 最大加速度に影響する要因として, (1)距離（震央 距離, 震源距離なよ゙), (2)地震マグニチュード, (3)地震 の発生メカ二ズム, (4)地震波の伝播経路（地表面付近の 地盤, 地款構造など), (5)観測地点周辺の地形, などを 考慮して精度を高める努力が数多くなされている とはいえ，はなはだしい团難さのゆえに，普遍性のある 推測法はいまだ見出されるに至っていない. 本論文の斜 面や土構造物の耐震設計・診断を考えるに当たっても， 上記の種々の項目を取り入れる試みをしたが，適切な表 現法がないことや資料不足のため，結局断念せざるを得 なかった。ただし，地震源の地域区分を考慮した点だけ は新しい点であり，これに基づき各地域ごとの距離減衰 式を提案することとした。

\section{（2）地域区分を考慮した最大加速度の距離減衰式}

建設省土木研究所と運輸省港湾技術研究所は, 強震計 による地盤加速度の測定結果を公表している20121).これ らの資料を用いて，1963 年から 1982 年の 20 年間に, 少なくとも 5 地点以上で地表面加速度が測定された 82 個の地震を選び出し, 図一3にその震央位置を示した. 地震の諸元, すなわち発生年月日, 震源位置 (緯度, 経度, 深度), 地震マグニチュードは気象庁の地震月報によっ $た^{22)}$. この 82 個の地震によって, 総計 886 個の地表面 加速度が得られている. 図一-3には, 日本海溝, 相模卜 ラフ，南海トラフならびに茂木 ${ }^{23)}$ が Gutenberg-Richter 式の $b$ 值が地款構造と関係していることを示すために 用いた地域区分線も破線で併記した.これらの区分線と， 82 個の地震の震央位置分布を勘案して, 点線で示すよ うな地域(A)～(F)の 6 地域に分割した.このような地域分 けにより地震波の伝播経路の相違を適切に表現しようと すれば，本来ならば，加速度測定地点の地域分けも考え るべきであるが，資料数に制限があったので，この点は 考慮せずに地表面加速度の重回帰分析を行った。重回帰 分析では,距離として震央距離と震源距離の両者を用い, 次式 ( 1 ) の係数 $b_{1}, b_{2}, b_{3}$ を求めた.

$$
A=b_{1} \cdot 10^{b_{2} M} \cdot\left(R+b_{4}\right)^{-b_{3}} \text {. }
$$

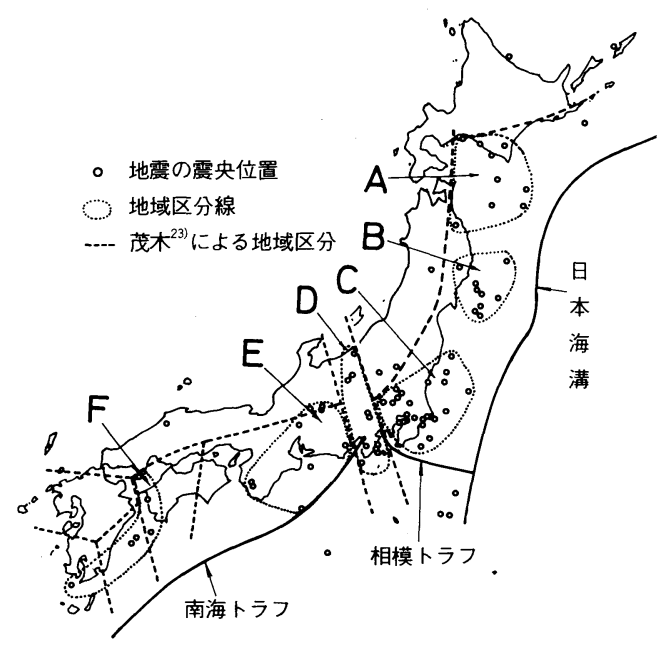

図一3距離娍衰式の回帰分析に用いた地震の震央位置 とその地域区分

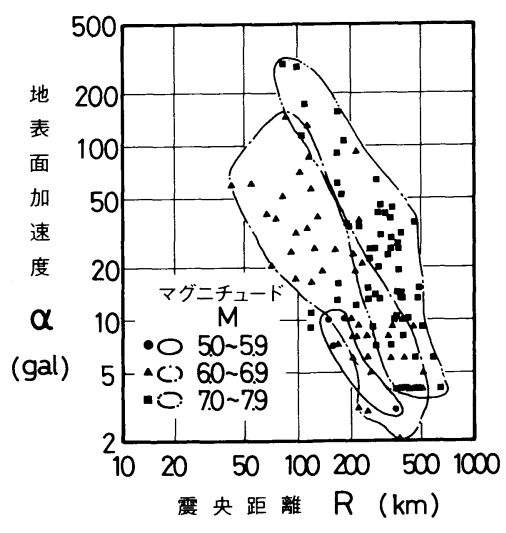

図一4 地表面加速度と震央距離の関係

ここに， $A$ は最大加速度 ( $\mathrm{gal}), M$ は地震マグニチュー ド, $R$ は距離 $(\mathrm{km})$ である. $b_{4}$ については岩崎らと同様 0 , $10,20,30(\mathrm{~km})$ の場合を計算したが, 震源距離, 震 央距離の場合とも重相関係数に大差はなかったので，こ こでは紙幅の都合により $R$ は震央距離, $b_{4}=0(\mathrm{~km})$ の 場合のみを示す.なお,この場合には $R=0$ で $A=\infty$ となるので，この式の適用範囲はデー夕の存在する $R$ $\fallingdotseq 20 \sim 1000 \mathrm{~km}$ とする.

図一4は，地域(B)で生じた地震で観測された地表面加 速度を地震マグニチュードのランク別に示したものであ る. ランクは $5.0 \sim 5.9,6.0 \sim 6.9,7.0 \sim 7.9$ とし, 各 ランクごとに值がばらついている範囲を示してあるが, これから地表面加速度に対する震央距離や地震マグニ チュードの影響がよくわかる.

図一5に，回帰式のみではあるが，特徴のある地域(B) と地域(Dの 2 例を示した. 図の繁雑さを避けるため, 観 
測点のプロットは省略してある. 地域(の場合には係数 $b_{3}$ が大，すなわち震央距離に対する地表面加速度の減 衰が大きい．また，地域(D)場合には係数 $b_{2}$ が小，す なわち地表面加速度に対する地震マグニチュードの影響 が小さい特徵がある.

表一1 は各地域ごと，ならびに収集した全加速度記録 886 個を用いた場合の重回帰分析結果の一覧表であり， 地震数, 加速度記録数, 回帰係数 $b_{1}, b_{2}, b_{3}$, 重相関 係数が示してある.この表から，図一5に示したように， 地域(B)係数 $b_{3}$ が他の地域よりも大きく，地域(D)係

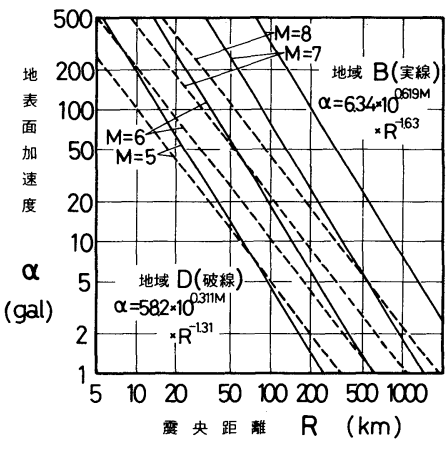

図-5 距離減衰式の回帰式

表一1 距離隇衰式の重回帰分析結果

\begin{tabular}{|c|c|c|c|c|c|c|}
\hline \multirow{2}{*}{ 地 域 } & \multirow{2}{*}{ 地震数 } & 加速度 & \multicolumn{3}{|c|}{ 回 帰 係 数 } & \multirow{2}{*}{ 重 相 } \\
\cline { 4 - 6 } & & 記録数 & $b_{1}$ & $b_{2}$ & $b_{3}$ & 関係数 \\
\hline $\mathrm{A}$ & 9 & 106 & 12.53 & 0.4830 & 1.356 & 0.725 \\
$\mathrm{~B}$ & 9 & 121 & 6.341 & 0.6188 & 1.631 & 0.779 \\
$\mathrm{C}$ & 26 & 283 & 3.702 & 0.5442 & 1.335 & 0.703 \\
$\mathrm{D}$ & 11 & 116 & 58.22 & 0.3107 & 1.311 & 0.728 \\
$\mathrm{E}$ & 9 & 78 & 288.8 & 0.2047 & 1.202 & 0.743 \\
$\mathrm{~F}$ & 6 & 57 & 25.38 & 0.4153 & 1.278 & 0.701 \\
\hline 全体 & 82 & 886 & 5.081 & 0.4630 & 1.144 & 0.670 \\
\hline
\end{tabular}

表一2 従来の距離減衰式

\begin{tabular}{|c|c|c|c|c|c|c|}
\hline \multirow{2}{*}{$\begin{array}{c}\text { 提案者 } \\
\text { 等 }\end{array}$} & \multirow{2}{*}{ 地震数 } & \multirow{2}{*}{$\begin{array}{l}\text { 加速度 } \\
\text { 記録数 }\end{array}$} & \multicolumn{2}{|c|}{ 回 帰 係 } & 数 & \multirow{2}{*}{$\begin{array}{l}\text { 重 相 } \\
\text { 関係数 }\end{array}$} \\
\hline & & & $b_{1}$ & $b_{2}$ & $b_{3}$ & \\
\hline $\begin{array}{l}\text { 岩崎ら } \\
\text { (地盤種 } \\
\text { 別を考虑) }\end{array}$ & - & 301 & 18.4 & 0.302 & 0.800 & 0.62 \\
\hline 第 1 種 & - & 29 & 28.5 & 0.207 & 0.598 & 0.48 \\
\hline 第2種 & - & 74 & 13.2 & 0.330 & 0.806 & 0.59 \\
\hline 第3種 & - & 127 & 32.1 & 0.254 & 0.757 & 0.61 \\
\hline 第4種 & - & 68 & 6.47 & 0.423 & 0.977 & 0.72 \\
\hline 片山 & 46 & 330 & 9.59 & 0.466 & 1.290 & 0.71 \\
\hline $\begin{array}{l}\text { 篠ら } \\
\text { (地盤種 } \\
\text { 別を考慮) }\end{array}$ & - & 723 & - & - & - & - \\
\hline 第1種 & - & - & 6.85 & 0.373 & 0.866 & 0.59 \\
\hline 第2種 & - & - & 6.75 & 0.351 & 0.793 & 0.60 \\
\hline 第3種 & - & - & 14.8 & 0.318 & 0.829 & 0.62 \\
\hline 第4種 & - & - & 4.45 & 0.420 & 0.922 & 0.67 \\
\hline
\end{tabular}

数 $b_{2}$ が他の地域よりも小さいことがわかる.ただし， 地域( $\mathrm{E}$ では係数 $b_{2}$ が小さく，地震マグニチュードの影 響がより小さいといえる. 残りの地域(A)，(C)，(F)の係数 $b_{2}$ は地域(B) (D)の中間の值となり, 係数 $b_{3}$ は地域(D ほぼ同じ值となる。このことは，地域(A)，(C)，()の場合， 地震マグニチュードの影響は図一5 の両者の中間的関係 を示し, 震央距離に対する地表面加速度の減衰性は地域 (D)場合に近いことを示している.

表一2に，岩崎ら ${ }^{12)}$, 片山 ${ }^{111)}$ ，篠ら ${ }^{17)} に よ る$ 同形式の 回帰式に基づく值を示した. 各式の提案に用いられた デー夕の質や量が異なるので単純な比較は行えないが, 表一1 の全デー夕を一組とした場合の回帰式の係数 $b_{1}$, $b_{2}, b_{3}$ 值は, 片山の場合の值に近いことがわかる. なお, 全加速度記録を用いた場合の重相関係数は 0.67 で，他 者によるものに比べそれほど高くないが，表一1の地域 分けを考慮したときの各地域の重相関係数は, すべてこ れらより大きくなっている.これは，土構造物の計画や 解析等に地域別の距離減衰式を用いることの優位性を示 している．ただし，地域®の結果を記入した図一1と地 域(Dの結果を記入した図一2をみればわかるように，回

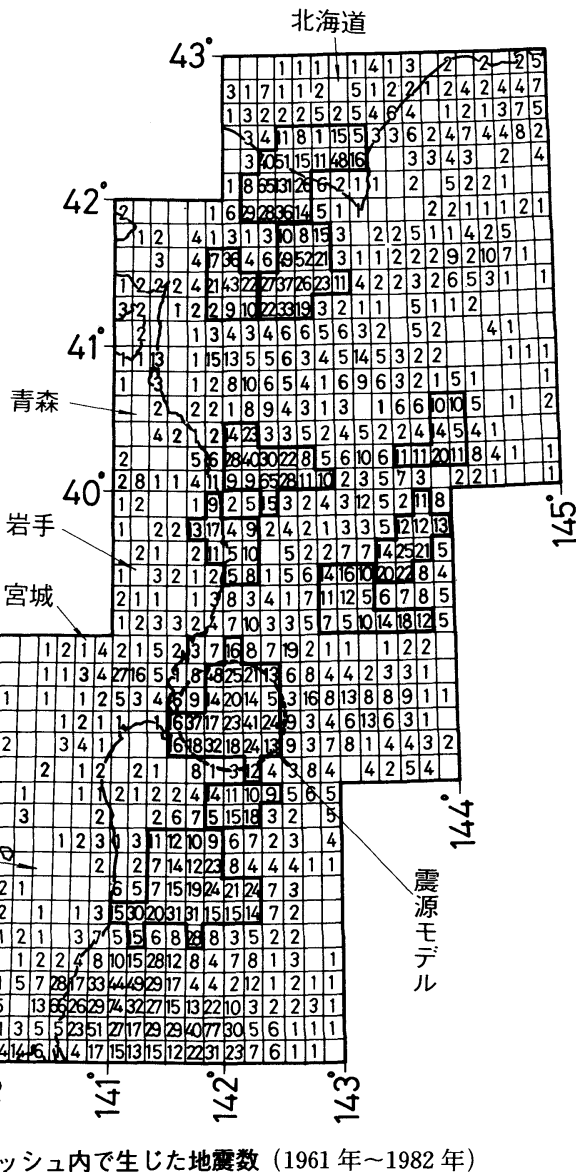


帰線の回りのばらつきはそれでもなおかなり大きい.こ の事実を認識しながらも，これ以上精度を上げる方法が ないので, 後の地震危険度解析にはこうして求めた地域 別の距離減衰式を適用する.

\section{3. 地震の巣と地震マグニチュード}

2. で求めた距離減衰式を建設予定地点の最大加速度 の推定に用いるにしても, 地震が発生する場所とその地 震マグニチュードを与える必要がある.

\section{(1) 地震の巣}

地震学では，地震活動の盛んな場所を“地震の巣”之 よんでいる ${ }^{24)}$. 前述の距離減衰式や震度と最大加速度の 関係では，距離として震央距離を用いているので，平面 的な“地震の巣”を決める必要がある。“地震の巣”や 地震マグニチュードの整理に関連して, 震源位置や地震 マグニチュードの決定精度, 地震検知能力が地域や深度 により異なる，などの問題 ${ }^{25)}$ があるが，これらの事実を 設計や解析に生かすには，まだ地震学的知識が不十分之 いわざるを得ない．そこでここでは，地震に関する構造 的議論には一切立ち入らず，工学的利用を目的とする観 点に絞って平面的な“地震の巣”を検討することとする.

気象庁では，日本およびその周辺で生じた地震をまと め，地震月報 ${ }^{22)} と し て$ 報告している，それには，地震の 発生年月日, 位置 (緯度, 経度, 深度), マグニチュー ドが記載されている．気象庁の地震観測体制が非常によ く整備されたのは 1961 年頃からといわれているので, ここでは 1961 年から 1982 年の 22 年間のデー夕を用い た.この間には, マグニチュード 3.0 以上の地震が約 20000 回発生したことが記録されている。これらの地震 の震央位置を緯度，経度 $10^{\prime}$ メッシュごとに集計し，そ の地震数を示した一例が図一6である.なお, 数字が記 入されていないメッシュは地震が生じていないことを意 味する.この図は, 北海道南部から関東北部にかけての 例であるが，地震が集中的に生じている所やそうでない 所が明白である，たとえば，襟裳岬の西から南 西部, 岩手県の沖合, 宮城県牡鹿半島の沖合, 福島県の沖合などに震央位置の集中が認められ る.この図には地震発生深度の情報が入ってい ないので，同一メッシュ内の地震が|必ずしも同 一震源のものかどうかはわからない.しかし, 前 述の最大加速度の距離減衰式や, 最大加速度と 逆算震度の関係 ${ }^{3)}$ を求めるときには震央距離 を用いているので，ここでは震央位置が集中し ている所を便宜上“地震の巣”とよぶ。それで もなお，必ずしも明確な境界線が引けるわけで はないが，一応図の太線枠で示すような平面的 な“地震の巣”を考えることにした。
（２）地震の巣で生ずる地震マグニチュード

地震マグニチュードの発生度数に関しては, それが地 震マグニチュードとともに指数的に減少するという, 著 名な Gutenberg-Richter の式がある.この関係から， あるマグニチュード以上の地震発生度数 $N_{M}$ とマグニ チュードの関係もやはり指数関係となり，次式で表わさ れる。

$\log N_{M}=a-b\left(m-m_{0}\right)$

ここに, $m_{0}$ は工学上問題としなければならない最小の 地震マグニチュードである. この式の係数 $b$ は, 従来 $0.7 \sim 1.0$ の値を示すといわれており ${ }^{24)}$, “地震の巣” の 性質を示す重要なパラメーターである. その他にも，地 震マグニチュードの度数分布そのものについての研究も ある.たとえば, Gutenberg-Richter 式の折れ曲がり点 の地震マグニチュードがその地殻構造と関係することを 示した茂木の研究 ${ }^{23)}$ や $b$ 值が指数分布の最尤推定に

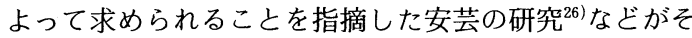
れであり,他に, 式 ( 2 ) と異なる式も提案されている ${ }^{24)}$.

まず, 図一6の平面的な“地震の巣”に関して, 式 ( 2 ) の関係をプロットしてみた。図一7はその代表的な例で •あり，図中の黒丸印はその地震マグニチュード以上の地 震個数である，同図（a）は宮城県牡鹿半島沖合の “地 震の巣”の場合であり，同図（b）は岩手県沖合の場合 である．図中の実線と破線は回帰分析の結果であるが， （a）の場合には小さな地震マグニチュードから Gutenberg-Richter の式に非常によくのっている，ただし，b 值は従来いわれている值より少し小さく 0.636 となっ ている．一方，(b) の場合には Gutenberg-Richter の 式から外れる領域がある。最小マグニチュード $m_{0}$ を 種々変化させたところ, $m_{0}=4.0$ のときに相関係数が 最も高く，その場合の $b$ 值は 0.990 となった.この図 には，地震マグニチュードの二次の項までを考慮した回 帰式も記入したが，これは非常によくデータを説明する ことがわかる，他の “地震の巣”に関しても，直線が合

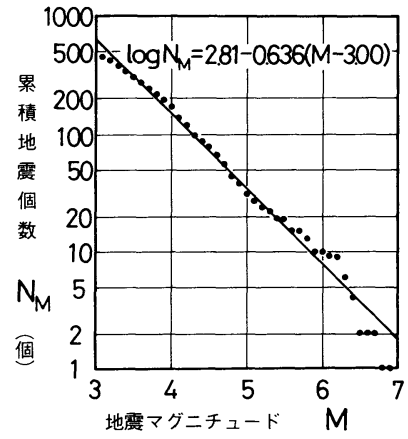

(a) 宮城県牡鹿半島沖合の場合

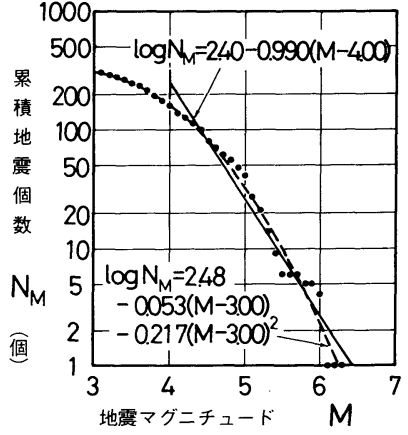

(b) 岩手県沖合の場合

図一7累積地震発生個数と地震マグニチュードの関係 
う場合と二次曲線が合う場合の両者があった．以上のこ とから, 平面的な “地震の巣”で生ずる地震マグニチュー ドの発生度数に関しては, 最小地震マグニチュードをど の程度にとるかの問題はあるものの，第一近似としては Gutenberg-Richter 式で十分表現できること，少し上に 凸の関係になる場合には二次の項までを考慮すればよい ことがわかる.

\section{4. 地震危険度解析}

\section{（1）方 法 論}

最大加速度の距離減衰式は基本的には式（1）の形式 でよい，ただし，本章では微積分の便利さゆえに式（1) の対数の底を $e$ にするので, 以下の各式における係数 $b_{2}$ は式 $(1)$ では $b_{2} \ln 10$ に相当する. なお，当然のこ とながら $b_{1}, b_{3}$ は同じである. さて, 斜面や土構造物 の地震危険度解析を震度 $K$ を用いて行うためには最大 加速度と震度の関係を導入しなければならない，前論文 では3)，実際事例の逆解析を通じて震度 $K$ と最大加速度 $A$ の関係を $2 つ$ 形式で表わした.すなわち，

$$
\begin{aligned}
& K=c_{1} \cdot A^{c_{2}} \ldots \\
& K=c_{1}^{\prime}+c_{2}^{\prime} A
\end{aligned}
$$

震度法・円弧すべり面法で耐震設計を行う場合，用いる 最大加速度は通常 100 400 gal である.この範囲にお いては上記両式に大差がないので，前論文では簡単な式 (3·b) を用いて議論を進めた。しかしながら, 本論文 で示す地震危険度解析においては確率統計的手法を用い る. したがって, 後に説明するように, 最大加速度の累 積分布関数が必要となる，そのため, 理論の構築上, 最 大加速度が $0 \mathrm{gal}$ 以上の全範囲にわたって（最大加速度 一震度）関係が定義されていなければならない。この場 合, 式 (3·b) では $A=0 \mathrm{gal}$ でも $K=c_{1}$ となり, 物理 的に不都合が生ずる．Aの小さな範囲の事例解析結果 はないが，工学的見地からみて，この範囲の影響はきわ めて小さいので, 数学的な整合性を図るため後の地震危 険度解析においては式 $(3 \cdot a)$ を仮定する．ただし，繰 り返すが，このことは前論文と矛盾することではなく， 問題となる最小の最大加速度が $100 \mathrm{gal}$ 程度以上であれ ば，式（3）のどちらを用いてもほぼ同様の地震危険度 解析結果が得られることがわかっているのである.

地震マグニチュードの発生度数に関しては，3．で述 ベたように第一近似としては Gutenberg-Richter 式で よい．したがって，地震マグニチュードの累積分布関数 $F_{M}(m)$, 確率密度関数 $f_{M}(m)$ は次式となる.

$$
\begin{aligned}
& F_{M}(m)= \begin{cases}0 \quad & m<m_{0} \\
1-\exp \left[-\beta\left(m-m_{0}\right)\right], & m_{0} \leqq m\end{cases} \\
& f_{M}(m)= \begin{cases}0 & , m<m_{0} \\
\beta \exp \left[-\beta\left(m-m_{0}\right)\right] & , m_{0} \leqq m\end{cases}
\end{aligned}
$$

ここに, $\beta$ は前述した式 $(1)$ と同様の理由により, $b \ln 10$ に相当する.

地震源モデルとしては, 図一6に示した平面的な “地 震の巣”を考慮し円形と仮定した. 円形震源モデルの利 点は, Cornell の扇状震源モデルとは異なり，建設予定 地点が震源からいかなる方向にあっても，その地震危険 度解析に必要な震源パラメーターが不変なことである。 ここにいう震源パラメーターとは, 震源モデルの半径 $l$, 地震マグニチュードの最小值 $m_{0}$, Gutenberg-Richter 式の $b$ 值, 地震平均発生率 $\nu$ である. さて, 図一 8 に 示すように円形震源モデルの端までの距離を $d$ とした 亡き, 距離 $R$ の累積分布関数 $F_{R}(r)$, 確率密度関数 $f_{R}(r)$ は次式となる。

$$
\begin{aligned}
F_{R}(r)= & \frac{1}{\pi}\left[x_{2}\left(1-x_{2}^{2}\right)^{\frac{1}{2}}+\sin ^{-1} x_{2}+\frac{\pi}{2}\right] \\
& -\frac{1}{\pi}\left(\frac{r}{l}\right)^{2}\left[x_{3}\left(1-x_{3}^{2}\right)^{\frac{1}{2}}+\sin ^{-1} x_{3}-\frac{\pi}{2}\right] \\
f_{R}(r)= & \frac{2}{\pi}\left(1-x_{2}^{2}\right)^{\frac{1}{2}} \frac{d x_{2}}{d r}-\frac{2}{\pi}\left(\frac{r}{l}\right)^{2}\left(1-x_{3}^{2}\right)^{\frac{1}{2}} \frac{d x_{3}}{d r} \\
& +\frac{r}{l^{2}}-\frac{2 r}{\pi l^{2}} x_{3}\left(1-x_{3}^{2}\right)^{\frac{1}{2}} \\
& -\frac{2 r}{\pi l^{2}} \sin ^{-1} x_{3}, \quad d \leqq r \leqq d+2 l \cdots \ldots . . . .
\end{aligned}
$$

ここに,

$$
\left.\begin{array}{l}
x_{2}=\frac{r^{2}-d^{2}-2 d l-2 l^{2}}{2 l(d+l)}, x_{3}=\frac{r^{2}+d(d+2 l)}{2 r(d+l)} \\
\frac{d x_{2}}{d r}=\frac{r}{l(d+l)}, \frac{d x_{3}}{d r}=\frac{r^{2}-d(d+2 l)}{2 r^{2}(d+l)}
\end{array}\right\}
$$

地震の発生過程を平均発生率 $\nu$ の゚゚アソン過程とす れば, 以上の仮定より, 建設予定地点の震度の確率分布 が求められる.

距離 $R=r$ で地震が生じたとき, 震度 $K$ がある值 $k$ を越える確率は，地震マグニチュードと距離が独立なら ば次式で与えられる.

$$
\begin{aligned}
& P[K \geqq k \mid R=r]=k^{-\frac{\beta}{c_{2} b_{2}}} \cdot\left(c_{1} b_{1}^{c_{2}}\right) \frac{\beta}{c_{2} b_{2}} \cdot e^{\beta m_{0}} \cdot r^{-\frac{b_{3} \beta}{b_{2} \beta},} \\
& k_{0} \leqq k
\end{aligned}
$$

震度 $K$ の累積分布関数を $F_{K}(k)$ とすれば,

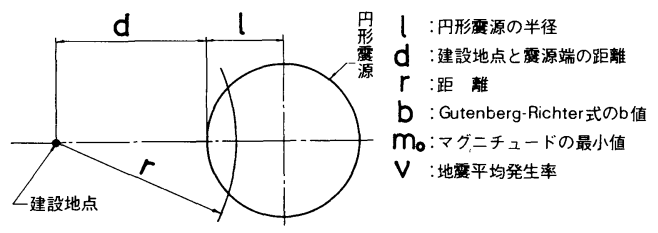

図一8 円形霞源モデル 


$$
\begin{aligned}
1-F_{K}(k) & =\int_{\boldsymbol{D}} P[K \geqq k \mid R=r] f_{R}(r) d \boldsymbol{D} \\
& =k^{-\frac{\beta}{c_{2} b_{2}}} \cdot\left(c_{1} \cdot b_{1}^{c_{2}} \frac{\boldsymbol{\beta}}{c_{2} b_{2}} \cdot e^{\beta m_{0}} \int_{\boldsymbol{D}} r^{-\frac{b_{3} \beta}{b_{2}} \beta} \cdot f_{R}(r) d \boldsymbol{D}\right. \\
& =C \cdot G \cdot k^{-\frac{\beta}{c_{2} b_{2}}} \ldots \ldots \ldots \ldots \ldots \ldots \ldots \ldots \ldots \ldots \ldots(8)
\end{aligned}
$$

ここに,

$$
C=\left(c_{1} b_{1}^{c_{2}}\right) \stackrel{\beta}{c_{2} b_{2}} \cdot e^{\beta m_{0}}, \quad G=\int_{\boldsymbol{D}} r^{-\frac{b_{2} \beta}{b_{2}} \cdot f_{R}} \cdot(r) d \boldsymbol{D}
$$

したがって, 建設予定地点で震度 $K$ がある值 $k$ 以上と なる確率は,

$$
p_{k}=P[K \geqq k]=C \cdot G \cdot k^{-\frac{\beta}{C_{2} b_{2}}} .
$$

となる. そして, ポアンン過程の性質より, 建設予定地 点で上記事象が生ずる過程もポアソン過程となるので, $t$ 年間の最大震度 $K_{\max }^{(t)}$ の累積分布関数は次式のように なる。

$$
P\left[K_{\max }^{(t)} \leqq k\right]=\exp \left[-\nu \cdot t \cdot C \cdot G \cdot k^{-\frac{\beta}{c_{2} b_{2}}}\right],
$$

$$
k_{0} \leqq k \cdots
$$

\section{（2）吉田川堤防の地震危険度解析}

上記方法論を用い, 吉田川堤防の地震危険度解析を 行ってみる.ここでは簡単のために, 図一6に示した宮 城県牡鹿半島沖の震源のみを考える. 図一6に仮定した 円形震源モデルを破線で示したが, 震源モデルの中心位 置は東経 $142^{\circ} 05^{\prime}$, 北緯 $38^{\circ} 27^{\prime}$ であり, 震源モデルの半 径は $l=43.5 \mathrm{~km}$ である. この地震源で生ずる地震マグ ニチュードの頻度分布は図一7 (a) であるから， $\beta=b$ $\ln 10=0.636 \ln 10=1.464$ となる. そして工学的に問題 とすべき最小の地震マグニチュード $m_{0}$ を 5.0 と仮定す ると, 平均発生率 $\nu=1.55$ 回/年となる. ちなみに, 吉田川解析地点における $m_{0}=5.0$ に対応する震度 $k_{0}$ は 0.024 である. また, 最大加速度の距離減衰式として は, 図一5 の地域(B)式を用いるので, $b_{1}=6.341, b_{2}$ $=0.6188 \ln 10=1.425, b_{3}=1.631$ が得られる. そして, 前論文 ${ }^{3)}$ の最大加速度亡震度の関係加ら, $c_{1}=0.00813$, $c_{2}=0.531$ である.

解析地点から地震源モデルの端までの距離は $d=71.5$ $\mathrm{km}$ であるから, 式 $(8)$ の $C=0.911$ となる. Gに関 しては, $f_{R}(r)$ が式 $(5)$ のように複雑な関数の 2 重積 分を必要とするので, 数值積分を実施した結果, $G=$ 0.000245 となった。 したがって,

$$
\left.\begin{array}{l}
F_{K}(k)=1-0.000223 k^{-1.935} \\
f_{K}(k)=0.000432 k^{-2.935}
\end{array}\right\}
$$

この $F_{K}(k)$ と $f_{K}(k)$ を図示すると, 図一 9 のようになる. また，

$$
P\left[K_{\max }^{(t)} \geqq k\right]=1-\exp \left[-0.000346 t \cdot k^{-1.935}\right] .
$$

を, 震度 $k$ をパラメーターとして示すと図一10のよう である. 震度 $k=0.10,0.20,0.30$, さらに参考のために, $0.13 ， 0.28$ の場合が示してあるが, 時間の経過ととも

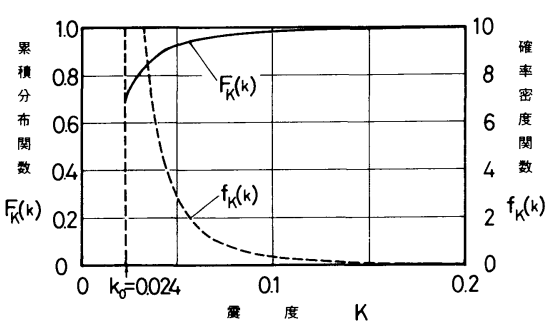

図-9 霞度の累積分布関数と確率密度関数

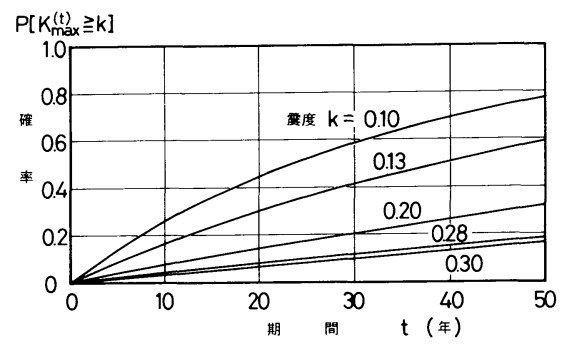

图一10 $P\left[\boldsymbol{K}_{\max }^{(t)} \geqq \boldsymbol{k}\right]$ と期間の関係

に確率 $P\left[K_{\max }^{(t)} \geqq k\right]$ の増加する定性的傾向がわかる. $k=0.13$ と 0.28 は吉田川堤防の一破壊事例の逆算震度 ならびにその破壊事例に隣接する非破壊事例が耐え得る 震度（前論文 ${ }^{3)}$ の事例 E-3）である.

図一10 は試算例であるから，その縦軸である $P\left[K_{\max }^{(t)}\right.$ $\geqq k]$ の值が堤防の破壊確率そのものを与えているとは 現在のところ考えていない，その理由として，(1)図一6 に示したように, 多くの震源があるにもかかわらず,こ こでは 1 つの震源しか考虑していないこと, (2)図一1や 図一2にみられるような距離減衰式自身がもつ変動を考 慮していないこと，(3)前論文 ${ }^{3)}$ に示したように（最大加 速度一震度）関係は平均值線のまわりにばらつくが，こ れを考慮していないこと，などが挙げられる.しかしな がら, たとえば, $k=0.13$ と $k=0.28$ の両曲線上で $t=$ 30 年に対する確率 $P\left[K_{\max }^{(t)} \geqq k\right]$ を比較してみると, 前 者は後者の約 3 倍となっており, これは両者の破壊しや すさの程度を大略比較したことにはなっていると考えて よい，換言すると，図一10はいまだ破壊確率の絶対値 を示す段階にまでは至っていないが，少なくとも斜面や 土構造物の危険箇所の相対的比較や対策工実施の優先順 位の決定なぼに有用な情報になり得ると考える.

\section{5. あとがき}

本論文で得られた結果を要約すると以下のようであ る.

（1）1978 年に生じた 2 つの大きな地震（宮城県沖 地震と伊豆大島近海地震）の際に観測された地表面加速 度の距離减衰特性はかなり異なると同時に, 従来提案さ 
れている距離減衰式では十分表現し得ないことがわかっ た.

（2）そこで，1963 年から 1982 年の 20 年間に生じ た地震 82 個によって観測された 886 個の地表面加速度 を用い，地震発生地点の地域区分を考虑した距離減衰式 を提案した.

（3） 1961 年から 1982 年の 22 年間に日本全体で生 じた約 20000 個の地震の震央位置を図示し, 震央位置 が集中する平面的な “地震の巣”を提示した。

（4）それぞれの“地震の巣”について地震マグニ チュードの整理を行った結果，一般に Gutenberg-Richter 式がよく合うことがわかった。 そして，これから 外れるケースでは地震マグニチュードの二次の項までを 考慮すれば十分であることがわかった。

（5）地震源モデルとして円形震源モデルを仮定し， 震度に基づく地震危険度解析の方法論を示した。

（6）宮城県牡鹿半島沖の震源のみを考え，その地震 源で生ずる地震マグニチュードの $b$ 值とその地域の地 表面加速度の距離減衰式を用いて吉田川堤防の地震危険 度解析を行った結果，宮城県沖地震時の破壊事例と非破 壊事例の確率 $P\left[K_{\max }^{(t)} \geqq k\right]$ の相違が明らかとなった。

最後に，加速度の距離减衰等について有益な助言をい ただいた東京大学 藤野陽三博士，ならびに地震資料， 加速度記録の整理を精力的に遂行していただいた名城大 学の牛田昌実, 岸 悟, 高田 聡, 竹中郁尊の各氏に謝 意を表する.

\section{参 考 文 献}

1）片山恒雄：地震活動度・危険度の確率論的な考え方, 生 産研究, 27 巻 5 号, pp.1 11, 1975.

2）松尾 稔・板橋一雄・佐々木康：実際事例の逆解析によ る土構造物の耐震性に関する研究, 土木学会論文報告集, 第 343 号, pp. 25 33, 1984.

3）松尾 稔・板橋一雄：斜面および土構造物の耐震性評価 に関する研究, 土木学会論文報告集, 第 352 号 /III - 2 , pp. 139 147, 1984.

4) Cornell, C.A. : Engineering Seismic Risk Analysis, Bulletin of the Seismological Society of America, Vol. 58, No. 5, pp. 1607 1620, 1968.

5) Kanai, K. : An Empirical Formula for the Spectrum of Strong Earthquake Motions, Bulletin of the Earthquake Research Institute, Vol. 39, pp. 85 95, 1961.

6) Esteva, L. and Rosenblueth, E. : Spectra of Earthquakes at Moderate and Large Distances, Soc. Mex. de Ing. Sismica, Mexico II, pp. 1 18, 1964.

7) Kawasumi, H. : Measures of Earthquake Danger and Expectancy of Maximum Intensity Throughout Japan as
Inferred from the Seismic Activity in Historical Times, Bulletin of the Earthquake Research Institute, Vol.29, pp. $469 \sim 482,1951$.

8）岡本舜三・田村重四郎・加藤勝行・小野公一郎：岩盤地 帯における地震動, 第 11 回地震工学研究発表会, pp. 53 $\sim 56,1971$.

9） 大崎順彦・渡辺 丹：地震動の最大值について, 日本建 築学会大会学術講演梗概集, pp. 525 526, 1977 .

10）勝又 護：地震動の最大加速度の推定, 験震時報, 第 37 巻, pp. 79 87, 1972

11) Katayama, T. : Statistical Analysis of Peak Accelerations of Recorded Earthquake Ground Motions, SeisanKenkyu, Vol. 26, No.1, pp. 18 20, 1974.

12）岩崎敏男・若林 進・常田賢一: 加速度記録の統計解析, 土木技術資料，Vol. 20，No. 4，pp. 28 32，1978。

13）川島一彦・相沢 興・高橋和之：最大地震動および地震 応答スペクトルの推定法, 土木研究所資料第 1993 号, 1983.

14）土木研究所第一次調查団：1978 年 6 月宮城県沖地震被害 調查速報，土木技術資料，Vol. 20，No. 8，pp. 40 51， 1978.

15）土田 肇・野田節男ほか：1978 年宮城県沖地震港湾被害 報告，港湾技研資料，No. $325 ， 1979$.

16）土木研究所調查団：1978 年 1 月伊豆大島近海地震調查概 要, 建設省土木研究所資料第 1346 号, 1978.

17）篠 泉・大角恒雄・片山恒雄：強震デー夕の統計解析に おける問題点, 第 37 回土木学会年次学術講演会概要集, 第 I 部会, pp. 659 660, 1982 .

18）後藤尚男・亀田弘行・杉戸真太：地震動の最大地動予測 における $N$ 值を用いた地盤条件の評価法, 土木学会論文 報告集，第 317 号, pp. 69 78, 1982.

19）太田外気晴・清田芳治：地震時の平均的加速度レベルに 及ぼす地款構造の影響, 鹿島建設技術研究所年報, 第 28 号, pp. 239 246, 1980.

20）建設省土木研究所：土木構造物における加速度強震記録， 土木研究所彙報.

21）運輸省港湾技術研究所：港湾地域強震観測年報，港湾技 術研究所資料.

22）気象庁：地震月報, 気象庁.

23) Mogi, K. : Regional Variations in Magnitude-Frequency Relation of Earthquakes, Bulletin of the Earthquake Research Institute, Vol.45, pp. 313 325, 1967.

24） 宇津徳治：地震学, 共立出版, 1977

25）勝又 護：日本列島およびその周辺におけるサイスミシ テとそれに関連する諸問題,験震時報,第 35 巻,第 3,4 号, pp. 1 68, 1970 .

26) Aki, K. : Maximum Likelihood Estimate of $b$ in the Formula $\log N=a-b M$ and its Confidence Limits, Bulletin of the Earthquake Research Institute, Vol.43, pp. $237 \sim 239,1965$.

(1985.2.4 • 受付) 